\title{
Evidence-free Policy: The Case of the National Injury Insurance Scheme
}

\author{
Mark Harrison ${ }^{1}$
}

\section{Abstract}

The Productivity Commission report 'Disability Care and Support' recommends tort liability be replaced by a compulsory, government-run, no-fault scheme. But theory and evidence indicate moving to a no-fault scheme will increase the accident rate. Even a move from non-risk-rated third-party insurance to non-risk-rated first-party insurance reduces incentives for care. A no-fault scheme is not superior to current policies; genuine reform will need to be informed by law and economics literature.

\section{Introduction}

In its 2011 'Disability Care and Support' report, the Productivity Commission (PC) concludes that the current State-based disability support system is 'underfunded, unfair, fragmented and inefficient' (PC 201 la: 2). It recommended replacing the State-based schemes with a National Disability Insurance Scheme (NDIS). Both political parties supported legislation to establish the scheme and a 0.5 percentage point increase in the Medicare levy to help fund it.

With all attention focused on multi-billion-dollar increases in spending on disability support, far less scrutiny was afforded the other recommendation in the Productivity Commission's report:

State and territory governments should create insurance schemes that would provide fully-funded care and support for all catastrophic injuries on a no-fault basis, and that would collectively constitute a National Injury Insurance Scheme (NIIS).

The NIIS would include all medical treatment, rehabilitation, home and vehicle modifications and care costs, and cover catastrophic injuries from motor vehicle, medical (excluding cases of cerebral palsy associated with pregnancy or birth, which would be covered by the NDIS), criminal

1 University of Wollongong, harrison@uow.edu.au 
and general accidents. Common law rights to sue for long-term care and support should be removed, though access to damages for pecuniary and economic loss, and general damages would remain. (PC 2011b: 88, Recommendation 18.1)

The Productivity Commission recommended that all states create no-fault motor accident insurance schemes by 2013, other forms of catastrophic injury be covered by 2015, and an inquiry be held in 2020 to examine widening coverage to damage for pecuniary and economic and to some non-catastrophic injuries (PC 2011b: 90, Recommendations 18.6, 18.7).

The PC estimates the NIIS would have cost an extra $\$ 830$ million a year in 2011 to be raised from increasing compulsory third-party insurance premiums for motor vehicles, medical indemnity premiums, surcharges on rail passengers, levies on boats, increased municipal rates and from general revenue (PC 2010b: 907, 913).

\section{The National Injury Insurance Scheme: A 'no evidence' based policy}

For a policy initiative to be worthy of the name 'reform' we must have some confidence, based on established theory or evidence, that it is likely to yield a net benefit to the community over time (Banks 2012: 107). ${ }^{2}$

There are over 20000 people with a 'catastrophic-level' injury in Australia, with up to a thousand being injured each year. Around half of all catastrophic injuries are the result of motor vehicle accidents, eight per cent are work related, 11 per cent arise from medical incidents, with the remaining 32 per cent are classed as general injuries, typically associated with sport and recreation activities, criminal assault and catastrophic falls (PC 2011b: 793).

Currently the Northern Territory, NSW, Victoria and Tasmania have no-fault insurance schemes for motor vehicle accidents, the other states have fault-based tort law liability, where an accident victim can only claim from a negligent injurer, who usually carries compulsory third-party insurance (PC 2011 b: 790). The PC's NIIS proposal involves major changes for all. Except for the Northern Territory (which abolished common law rights to sue for transport accidents), the current no-fault schemes are 'add-ons', with limited no-fault benefits. They

2 Gary Banks was Chairman of the Productivity Commission from 1998 to 2012. 
preserve the right to sue for damages under tort law and apply only to motor vehicle accidents. Some require a threshold level of damage to sue under common law; others do not restrict access to tort actions (Luntz et al. 2009: 53-6).

Ironically, it falls to mainly Coalition state governments to implement this longstanding Labor Party policy. In 1973, the Whitlam Government appointed the architect of New Zealand's no-fault accident scheme, Sir Owen Woodhouse, to chair a Committee of Inquiry into a National Rehabilitation and Compensation Scheme for Personal Injury in Australia. It duly recommended a similar scheme for Australia, and the Whitlam Government put legislation to Parliament in 1974 to implement a national no-fault scheme. It did not pass the Senate amidst doubts whether the Commonwealth had power to abolish State tort rights. All Australian States rejected the Woodhouse Committee's recommendation that common law actions be abolished. Whitlam later introduced a redraft as a private member's bill in February 1977 whilst Leader of the Opposition, but it was not successful. A national no-fault compensation scheme was part of the Labor Party's 1983 election platform (Drabsch 2005: 20-3).

The States have agreed to introduce no-fault lifetime care and support for people who are catastrophically injured in motor vehicle accidents prior to the commencement of the NDIS launch (COAG undated: 18). NSW and South Australia have announced plans to convert their compulsory third-party car insurance arrangements, where drivers must insure against the risk of being held legally liable to another (the 'third party'), into compulsory first-party nofault schemes, where the policy holder (the first party) is insured against the risk of suffering loss.

\section{The lessons of the law and economics literature}

No small factor in the acceptance of both the NDIS and NIIS was the imprimatur of the widely respected PC. What has gone completely unremarked is the quality of the policy analysis in the PC's report.

The PC claims that in the presence of insurance, especially with little focus on risk-rating for some causes of injury, the common law does not provide incentives for prudent behaviour by motorists and other parties' (PC 2011b: 789); and that no-fault insurance would 'currently perform no worse at deterring excessively risky behaviour, as despite the appearance of the common law, it is the insurer that pays' (ibid).

These statements ignore and contradict the vast theoretical and empirical law and economics literature on the very issues examined in the Commission's 
report: the effect of tort law and different liability arrangements, insurance, litigation costs, settlement, regulation and criminal sanctions and no-fault insurance schemes.

In the report's 70-plus pages of references there are only three law and economics articles, only one article with 'no fault' in the title (although that one is from Agenda) and the PC does not refer to any of the top law and economics journals, law and economics textbooks, empirical or theoretical law and economics survey articles (such as in the New Palgrave Dictionary of Economics and the Law, The Handbook of Law and Economics, or the Encyclopedia of Law and Economics where the article on no-fault insurance is written by an Australian, McEwin 2000), or any of the pioneers of law and economics, such as Calabresi, Posner or Shavell or their classic and still fundamental books on accidents such as Shavell (1987), Landes and Posner (1987), or Calabresi (1968). Some of these were cited in PC (2004) and some are in the PC's own library.

The PC criticises how the current fault-based system compensates accident victims: with poor coverage (it covers only a small sub-set of losses: where there is a negligent party to sue) and high legal costs. It also denounces lump-sum payments, uncertain court outcomes, delays and settlement procedures.

The law and economics approach takes the objective of the legal system regarding accidents to be the minimisation of their total social costs: the costs of prevention, the costs of injuries that nonetheless occur, the costs of administration (such as litigation costs) and the costs of risk bearing. The law and economics approach agrees that insurance is much better than the liability system as a means of compensating risk-averse victims against loss, but emphasises the effect of the liability system on incentives to reduce risk through the deterrence of harm. It is true that tort law is a costly and incomplete form of compensation, but the litigation costs may be worth bearing if they cause enough efficient deterrence. The issue is which system is socially most efficient given overall costs and benefits, which include administrative and legal costs.

Third-party insurance indemnifies vehicle owners and drivers who are legally liable for personal injury caused to any other party in the event of a motor vehicle accident. The PC claims that compulsory third-party insurance removes any incentives for care, so that replacing the current system with no-fault insurance would not increase accidents.

But the PC ignores here a fundamental contribution of the law and economics literature: the idea of bilateral care or joint causation. The chance of an accident depends on the actions of both the injurer and victim. How common-law tort liability solves the bilateral care problem is one of the intellectual achievements of law and economics (see Shavell 1987; Landes and Posner 1987). The incentive 
not to be found negligent and avoid liability gives the injurer an incentive to meet the court-determined standard of due care. If the injurer takes due care, the accident costs are borne by the victim, who then has the incentive to take an efficient level of care.

It is true that if premiums cannot be adjusted in response to care taken, then third-party insurance will reduce the insured's care, the so-called moral hazard problem. But tort law still affects the victim's incentive. If the injurer is negligent, the victim may claim compensation from the insurer of the owner/driver of the 'at-fault' vehicle. But if the victim is also at fault, the compensation may be reduced under contributory negligence. The victim's damages are reduced according to the claimant's share of the responsibility for the accident (what economists call 'comparative negligence') (Luntz et al. 2009: 322). This provides an incentive for the victim to meet the standard of due care set by the courts, in order to preserve his right to damages.

In his devastating critique of the same arguments for abolishing negligence law from the New South Wales Law Reform Commission, Swan (1984) writes:

...even if the defendant in negligence actions is taken care of by the insurer so that both negligent and non-negligent drivers still pay the same third-party premiums, this still leaves the would-be plaintiff and victim who is denied compensation if shown to be negligent. It is surprising the Commission should believe that with potentially tens of thousands if not close to a million dollars at stake in some cases, that negligence laws have no deterrent effect. By comparison fines and penalties for drunkdriving, disobeying road laws, etc., are generally small in comparison even if a conviction can be obtained. In fact the very severity of the penalties for negligent behaviour under the fault laws often gives rise to claims that 'no-fault' should be introduced because fault laws are too harsh. Advocates of 'no-fault' cannot have their cake and eat it too. Either the fault system does not deter or has penalties which are too severe but not both (Swan 1984: 100).

Victims' care is particularly important in motor vehicle accidents, where a substantial portion of accidents involve motor vehicles crashing into each other. In 2010, multi-vehicle crashes were 42 per cent of Australian fatal road traffic accidents (ABS 2013: 4). Drivers cannot be sure in advance whether they will be an injurer or a victim. Even with compulsory third-party insurance, tort law gives drivers an incentive to be careful in their role as victims. 
In summary, no-fault insurance would reduce the victim's incentive for care. Under a no-fault scheme, drivers are guaranteed compensation even if unlicensed, speeding and blind drunk - and are treated the same as people they crash into.

No-fault insurance will, therefore, increase the number and cost of accidents. The amount depends on the importance of victim's care and its response to changes in incentives. Exactly how much deterrence tort law provides is ultimately an empirical question.

The PC proposes extending no-fault insurance to cover all general accidents. Many would not currently involve third-party insurance, so compulsory firstparty insurance will reduce incentives for injurer and victim care. For example, self-inflicted accidents would be covered - such as falling off ladders or singlevehicle accidents - which accounted for 44 per cent of fatal road traffic accidents in Australia in 2010 (ABS 2013: 4). When no other person contributes to, or is involved in, the accident, the costs of these accidents tend to be internalised and efficient levels of accident prevention adopted (the victim and injurer are the same person). Moreover, people can choose to take out first-party insurance and internalise the resulting moral hazard costs. Introducing compulsory nofault insurance for general accidents, financed through municipal rates, will externalise costs to taxpayers, reducing the incentives for care. Again, the extent to which accidents increase is an empirical matter.

A further law and economics insight that the PC ignores is the incentive legal and insurance arrangements give for excessive activity levels. Only observable precautions can be made part of the court's standard of due care, and the prospect of being found negligent does not encourage parties to take costjustified precautions that the court cannot observe. The activity level is the extent of participation in the activity that is the source of the accident, such as kilometres driven. Usually courts do not include the activity level in the required standard of care, because they cannot observe it or judge whether it is excessive. The court can judge whether the driver was negligent in how he drove but not whether he was negligent in how much he drove - whether his marginal trip was worth taking, given the expected accident costs it produced.

Expected accident losses depend not only on the care exercised by each party but also on each party's activity level. For example, the number of car accidents depends on how many kilometres are driven.

Under a negligence rule, drivers drive too much, since having taken the efficient level of precaution they are no longer liable for damages. Injurers do not bear the full social costs of their activity, but impose an external cost on accident 
victims, who bear their accident costs. Injurers only consider their net benefits from extra participation in the activity but not the increase in expected victim accident costs, resulting in excessive activity levels.

Under compulsory third-party insurance, accident costs are externalised onto the insurance company. But the premium charged to drivers will reflect this cost - internalising this cost for the participation decision (whether to drive at all), which may deter some from becoming drivers (such as young high-risk drivers). But as insurance premiums are some fixed annual amount and do not vary with kilometres driven, if the driver chooses to participate, then there is still an incentive for excessive activity levels (that is, to drive too many kilometres), with accident costs externalised across premiums for all drivers. If damages under-compensate accident victims, then they bear some of the external cost as well.

The per-kilometre accident externality is significant. Connelly and Supangan (2006) estimated the total costs of road traffic crashes in Australia as \$17 billion in 2003, equivalent to 2.3 per cent of that year's GDP (Clarke and Prentice 2009: 54). Motor vehicles in Australia travelled an estimated 201497 million kilometres in the 12 months ended 31 October 2003 (ABS 2003), so accident costs averaged around 8.4 cents per vehicle kilometre. More than half these costs are external (single-vehicle accidents are less than half of accidents, and all the costs borne by victims of other accidents are external).

No-fault insurance exacerbates the activity level externality. It increases the accident externality per kilometre through reducing care and covers a greater portion of victim accident costs (externalising more accident costs). The PC does not consider this externality or policies to combat it, such as per-kilometre insurance premiums.

The extent to which replacing the negligence rule with no-fault insurance will increase accident costs through reducing care and increasing activity levels is an empirical issue. The PC asserts: 'Nor is there evidence that the common law right to sue for compensation for care costs increases incentives for prudent behaviour by drivers, doctors and other parties' (PC 2011b: 43).

As Swan (1984: 100) points out:

Typically with statements like these denying the efficacy of the tort system there is a certain shyness towards coming to grips with the evidence. Perhaps the feeling is that it is better to allow an assertion to stand unadorned with supporting evidence when there is little or none available and to conveniently not be aware of statistical and econometric evidence which may reach different conclusions. 
The claim that there is no evidence that the right to sue for compensation creates incentives for prudent behaviour is simply false, as Googling the words 'empirical evidence no-fault insurance' reveals. Adding the word 'Australia' to your search leads you to studies on the effect of the various State-level nofault insurance schemes. The only evidence the PC cites (PC 2011b: 837-8) for its conclusion is a statement from Cane (2007: 55-6, 69), a distinguished law professor:

There is a significant body of empirical research about the deterrent efficacy of the tort system, which can perhaps be summarised by saying that tort law has more deterrent effect in some contexts than others, but in no context does it deter as effectively as economic theory of tort law would suggest. ... the conclusion that tort law is not worth what it costs is an attractive one.

Cane (2007) in turn cites one reference to support his statement, Schwartz (1994), which surveys the empirical literature on tort. Schwartz (1994: 443) does state that tort law is not 'as effective as economic models suggest' (whatever that means) but he recognises that tort law covers different fields, with different characteristics, and there is no reason why deterrence should be the same across all of them. He surveys four fields: workers' injuries, motorist liability (including no-fault schemes), medical malpractice and products liability. He concludes (pp. $379,444)$ :

...tort law provides a significant amount of deterrence ... the Article considers how much deterrence tort law needs to achieve if the tort system is to provide deterrence benefits that justify its various costs. The Article here develops findings about the medical malpractice system and the auto liability system that are tentatively favorable. Even conceding their tentativeness, these findings highlight the public policy value that can flow from even the moderate amount of deterrence that the tort system can provide. ... sector-by-sector, tort law provides something significant by way of deterrence.

Yet the PC and Cane cite it in support of precisely the opposite conclusion. The Schwartz conclusion is supported by a vast empirical literature on medical malpractice and no-fault motor vehicle insurance, including studies by economists McEwin (1989) and Swan (1984) of the Australian experience with no-fault schemes, which the PC simply ignores.

The other surveys of the empirical evidence come to the same conclusion as Schwartz. For example, Dewees et al. (1996: v) note:

Following this review of the evidence, we conclude that the deterrent properties of the tort system seem strongest for auto accidents and 
weakest for environmentally related accidents. The incentive effects of the system are mixed in the case of medical and product-related accidents, making net welfare judgments problematic; in the case of workplace accidents, workers' compensation levies appear to have stronger deterrent effects than the tort system did have or might have if it were resurrected in this context.

Other surveys include van Velthoven (2009), Sloan and Chepke (2007) and Liao and White (2002). The surveys summarise dozens of studies on the effects of medical malpractice liability and no-fault insurance.

\section{The lessons of experience}

The studies of no-fault insurance usually examine the effect of a shift to no-fault insurance on motor vehicle accident deaths, despite many no-fault schemes leaving tort liability intact in death cases. The justification is the probabilistic nature of accidents - less care means more accidents and some fraction will be fatal (Posner 2011: 258).

The results differ greatly — some finding shifting to no-fault in various states in the U.S. had no effect, others finding a 15 per cent increase in deaths. That is to be expected, as the switch to no-fault involves changes in liability rules and in insurance arrangements. The effect of introducing no-fault insurance depends on the system before it was introduced (such as liability insurance arrangements) and the details of the scheme introduced. For example, many schemes (as in NSW and Victoria) retain large elements of tort law and provide relatively modest no-liability benefits. For example, many no-fault schemes exclude damages for pain and suffering, and so under-compensate victims (which increases victim care costs).

The most relevant studies for the NIIS proposal examine the effects of a shift to a pure no-fault scheme that abolishes tort liability, as in New Zealand or for motor vehicles in Quebec and the Northern Territory. Swan (1984) and McEwin (1989) present empirical evidence on the switch to no-fault in New Zealand and the Northern Territory, compared to other states of Australia, and find it to be associated with a substantial increase of 16 to 20 per cent in the number of road fatalities. In Quebec, fatalities increased between 3 and 9 per cent (see, for example, van Velthoven 2009: 475; and Dewees et al. 1996: 25). Hause (1995) finds little initial effect of the NZ scheme on overall fatality rates, but a modest long-run trend effect in increasing fatal accident rates over what they otherwise would have been. 
Clearly there is a trade-off that the PC ignores. No-fault insurance may compensate victims better, but is likely to increase accident costs. It is a difficult policy issue - what are the equity effects of helping those with catastrophic injuries, but creating more people in those circumstances? It doesn't help to assume the trade-off doesn't exist.

Further, the trade-off may vary across different types of activities. For example, in many medical accidents, victim's care is not particularly important (although patients need to take their medicine). But it clearly is in work accidents and product liability. On the other hand, protecting their reputation gives doctors an incentive to avoid being found negligent. Many people think that the avoidance of negligence results in too much medical practice conducted not to ensure the health of the patient, but to safeguard against malpractice liability.

The PC reviews existing arrangements and the mechanics of bringing the different activities under a NIIS, but does not provide separate justifications for moving to no-fault for medical accidents, motor vehicle accidents, criminal injuries and household accidents. There is no analysis of the trade-off in each case because the PC assumes there is no trade-off.

Moreover, the PC doesn't seem to realise that motor vehicle accidents, involving accidents between strangers who cannot negotiate beforehand, is a different case from medical malpractice and workers' compensation, with different theoretical and empirical literatures. In medical and workplace settings, the parties voluntarily enter a contractual relationship, can negotiate beforehand and there is a market price that can adjust in response to different liability and insurance arrangements. Liability rules have less effect. Well-conceived liability rules might differ as between categories such as motor vehicle accidents, workplace accidents, medical malpractice and product liability.

Further, the PC pushes for a national scheme on the basis that 'there is little rationale for the striking differences between the states' (PC 2010b: 789). But once it is realised the optimal scheme involves trade-offs, and these trade-offs differ between states, then there is no reason why the same policy is best for all states. For example, the PC draw attention to the 'complex challenge' of the extremely high serious-injury accident rate in the Northern Territory, which it puts down to 'the special circumstances of the Northern Territory' (PC 2010b: 908). Either the Northern Territory's high accident rate is because it is the only state to have abolished tort law rights for motor accident victims (the PC's preferred scheme) or because it is different from other states. The trade-offs relevant for accident policy depend on the number and severity of accidents and how they respond to changes. The best policy for a high-accident state could be a no-fault scheme (because of greater administrative cost savings and 
there may not be much effect on care for whatever reason). It is not surprising that the Northern Territory has a different policy from the rest of Australia and not necessarily desirable that the rest of Australia adopt that policy.

\section{The way of genuine reform}

The PC recommends tort liability be replaced a compulsory, government-run, no-fault scheme (PC 2010: 848-9); it does not consider other possible reforms. The fault-based system is combined with a highly regulated insurance market. Rather than considering the best way to reform the current insurance market and legal regime, the PC simply recommends abolishing both. But good policy analysis would examine the liability system, insurance arrangements and their interaction, diagnose the accident system's faults and identify the best way to improve matters. For example, would reform of tort law be a better option? A per-kilometre tax? Strict liability? Why isn't a mixed approach of no-fault and fault-based liability, where victims are allowed to opt out and sue injurers under the tort system if their losses exceed a threshold (as in NSW, Victoria and Tasmania), a better approach? It is identical to the pure tort rule if the threshold is zero and identical to the pure no-fault rule if the threshold is infinite. Liao and White (2002) find that whether a pure tort, pure no-fault or a mixed system is best depends on factors like the court error rate, but they abstract from insurance market interactions.

Even if it is agreed that a pure no-fault insurance is superior to fault-based liability, where is the analysis establishing the case for compulsion and government monopoly in insurance provision? For example, private insurance markets may not exist because, once insured, people no longer take care and this moral hazard makes premiums too expensive. A government scheme faces the same moral hazard problems, and would be inefficient to introduce. Why do so few people take out first-party insurance for accidents? Is making it compulsory really the best response? Should we have a government monopoly on its provision? Should we have risk-rating? Per-kilometre premiums? ${ }^{3}$

The PC recommends including household accidents and criminal compensation, to be funded out of local rate increases. There is no analysis of the likely effects on accidents, interactions with current insurance markets, why private markets

3 One advantage of a federal system is the ability of states to experiment with different policies - which could then be adopted by other states if successful. The PC does not draw any lessons from the different insurance and compensation arrangements in the states. It does not conduct, or refer to, any empirical work on the costs and benefits of the different insurance arrangements (such as the different types of no-fault schemes). 
have failed and this is the best response, or how current criminal compensation schemes (all states have one) have worked and why expanding them is appropriate.

Government-run insurance schemes are very different from private insurance arrangements. Private companies attempt to deal with the moral hazard effect of insurance through partial insurance coverage (through deductibles or coinsurance), experience-rating (such as raising future premiums if there is a claim on the policy through the use of no-claim bonuses) and risk-rating: charging different prices to people with different risks (for example, discounts for those with car alarms), which sends a price signal to people engaging in risky behaviour. They may make a reduction in risk a precondition for issuing an insurance policy. Because of political incentives, providers of compulsory thirdparty insurance are often regulated to prevent them from taking these measures to control moral hazard. Government monopolies simply charge a uniform premium, or cover costs through taxes and levies. Charging the same premium to groups of people with different risks means the safer groups subsidise the more dangerous groups. More high-risk people participate in the activity when they face higher premiums, increasing overall risk and average premiums.

The PC agrees risk-rating has not been politically acceptable in compulsory third-party insurance, and argues it could be undertaken in a no-fault scheme, though it stops short of recommending it (PC 2010b: 833-6). Clearly a government agency has less incentive to reduce risk and discourage risky behaviour, because those risks are covered by others. The agency's political support comes from helping, not criticising. (Sowell 2004: 136). Government agencies seldom have enough assets to cover liabilities, but rely on pay-as-you-go — making current payments out of general revenue. As taxes distort decisions, financing insurance payouts with taxes incurs an additional excess burden. In contrast with a market system of insurance, cross-subsidies (including from future generations) are not competed away.

State-run insurance schemes are prone to excessive use, poor control of claims, inattention to rehabilitation and expansion of their scope. Accident victims face ever-changing rules on benefits and eligibility - they have no policy contract on which they can rely (Kerr 1996: 6). The New Zealand Business Roundtable (NZBR 1998: 145) points out:

State control of accident insurance in New Zealand does not appear to have induced state agencies to produce meaningful measures for monitoring the Corporation's performance with respect to the accident prevention objective, nor to assess the performance of New Zealand's no-liability arrangement or its occupational health and safety regulations. Instead, 
heroically massaged figures are used in a departmental publication to make a case for greater government expenditure and regulatory effort, rather than to evaluate the efficacy of existing programmes.

By establishing a government monopoly, the PC entrenches these distortions of the insurance market, rather than recommending reforms to improve its operation.

Theory and evidence suggest that moving to a no-fault scheme will increase the accident rate. Even a move from non-risk-rated third-party insurance to nonrisk-rated first-party insurance reduces incentives for care. A no-fault scheme is not a costless panacea evidently superior to current policies. Policy analysis is about weighing up the costs and benefits of various imperfect options and institutional arrangements. That is complex and requires a theoretical framework - which law and economics provides.

\section{References}

Australian Bureau of Statistics (ABS) 2003, 'Survey of Motor Vehicle Use, Australia', 9208.0, October, http://www.abs.gov.au/AUSSTATS/abs@.nsf/Prod uctsbyReleaseDate/3EAAB384EF8D2F62CA2570800072002D?OpenDocument

\section{0 .}

Banks, G. 2012, Advancing the Reform Agenda: Selected Speeches, Productivity Commission, Canberra.

Calabresi, G. 1970, The Cost of Accidents, Yale University Press, New Haven.

Cane, P. 2007, 'The Political Economy of Personal Injury Law', The Macpherson Lecture Series, University of Queensland Press, St. Lucia, Queensland.

Clarke, H. and Prentice, D. 2009, 'A Conceptual Framework for the Reform of Taxes Related to Roads and Transport', Prepared for the Treasury, Canberra.

Connelly, L. and Supangan, R. 2006, 'The economic costs of road traffic crashes: Australia, states and territories', Accident Analysis and Prevention 38(6): 1087-93.

Council of Australian Governments (COAG), undated, 'Intergovernmental Agreement for the National Disability Insurance Scheme (NDIS) Launch'.

Dewees, D., Duff, D. and Trebilcock, M. 1996, Exploring the Domain of Accident Law: Taking the Facts Seriously, New York: Oxford University Press. 
Drabsch, T. 2005, 'No Fault Compensation', NSW Parliamentary Library Research Service Briefing Paper No 6/05.

Harpwood, V. 2009, Modern Tort Law (7th edition), Routledge-Cavendish.

Hause, J. 1995, ‘Fatal Encounters: An Economic Theory of Accidental Injury with Application to New Zealand's No-Fault System', George J. Stigler Center for the Study of the Economy and the State, The University of Chicago, Working Paper Series No. 116.

Kerr, R. 1996, 'New Zealand's ACC Scheme: Time for a Decent Burial', Hutt Valley Chamber of Commerce and Industry, Wellington, 15 July.

Landes, W. and Posner, R. 1987, The Economic Structure of Tort Law, Harvard University Press, Cambridge, Massachusetts; London, England.

Liao, Y.-P. and White, M. J. 2002, 'No-fault for motor vehicles: An economic analysis', American Law and Economics Review 4(2): 258.

Luntz, H., Hambly, D., Burns, K., Dietrich, J. and Foster, N. 2009, Torts Cases and Commentary (6th edition), LexisNexis Butterworth.

McEwin, R. I. 2000, 'No fault compensation schemes', Encyclopedia of Law and Economics, Cheltenham, Edward Elgar. http://encyclo.findlaw. com/3600book.pdf

- 1989, 'No-Fault and Road Accidents: Some Australasian Evidence', International Review of Law and Economics 9: 13-24.

New Zealand Business Roundtable (NZBR), 1995, Accident Compensation: Options for Reform, New Zealand Business Roundtable, Wellington, New Zealand, September.

Posner, R. 2011, Economic Analysis of Law (8th edition), Wolters Kluwer.

Productivity Commission 2011a, Disability Care and Support: Overview and Recommendations Report no. 54, Canberra.

—., 2011b, Disability Care and Support, Report no. 54, Canberra.

- 2004, National Workers' Compensation and Occupational Health and Safety Frameworks, Report No. 27, Canberra, March.

Schwartz, G. 1994, 'Reality in the Economic Analysis of Tort Law: Does Tort Law Really Deter?' UCLA Law Review 377: 42.

Shavell, S. 1987, Economic Analysis of Accident Law, Harvard University Press, Cambridge, Massachusetts; London, England. 
Sloan, F. and Chepke, L. 2007, 'The Law and Economics of Public Health', Foundations and Trends in Microeconomics 3(5-6): 331-490.

Sowell, T. 2004, Applied Economics Thinking Beyond Stage One, Basic Books.

Swan, P. 1984, 'The Economics of Law: Economic Imperialism in Negligence Law, No Fault Insurance, Occupational Licensing and Criminology?' Australian Economic Review, 3rd Quarter: 92-108.

van Velthoven, B. 2009, 'Empirics of tort' in Tort Law and Economics, M. Faure (ed.), (vol. 1 Encyclopedia of Law and Economics, 2nd edition) Edward Elgar, Cheltenham, UK, Northampton, MA, USA: ch.16: 377-405. 